\title{
Synthesis and Effects of Two Peptide Fragments of Thymopoietin II on E-Rosette Forming Cells in the Uremic State ${ }^{1)}$
}

\author{
Takashi Abiko, Mihoko Kumikawa, and Hiroshi Sekino \\ Kidney Center, Sendai Insurance Hospital ${ }^{2}$
}

(Received March 8, 1979)

\begin{abstract}
Two peptides, H-Lys-Asp-Val-Tyr-Val-Gln-Leu-Tyr-Leu-OH and H-Arg-LysAsp-Val-Tyr-Val-Gln-Leu-Tyr-Leu-OH (fragment of thymopoietin II), were synthesized in a conventional manner utilizing the hydrogen fluoride procedure, and were tested to determine their effects on E-rosette forming cells in the uremic state. The synthetic decapeptide increased E-rosette forming capacity in the presence of uremic serum. The synthetic nonapeptide had no effect on the E-rosette formation inhibiting activity of uremic serum.
\end{abstract}

Keywords —uremic state; thymopoietin II; uremic serum; E-rosette; terminal chronic renal failure

The amino acid sequence of bovine thymopoietin II was elucidated by Goldstein et al. ${ }^{3}$ ) This $T$ cell differentiating hormone of thymus is a single 49-amino acid polypeptide chain. ${ }^{3}$ Chemical synthesis of a tridecapeptide with an amino acid sequence corresponding to positions 29-41 of thymopoietin II (H-Gly-Glu-Gln-Arg-Lys-Asp-Val-Tyr-Val-Gln-Leu-Tyr-Leu$\mathrm{OH})$ was reported Goldstein $e t a l,{ }^{4)}$ and they showed it to have selective $\mathrm{T}$ cell differentiating capacity like that of thymopoietin. II. Their data established that the key residues involved in the active site of thymopoietin II are present within this synthetic tridecapeptide, which constitutes only a minor portion of the amino acid sequence of thymopoietin II. ${ }^{4}$ Various fragment peptides of biologically active peptides have been shown to possess in vitro biological activity much higher than that of the parent peptides. ${ }^{5)}$

On the other hand, cell mediated immunity is impaired in the uremic state. ${ }^{6-8)}$ For example, skin graft rejection is usually delayed ${ }^{6)}$ and E-rosette inhibiting activity of uremic serum is also observed. ${ }^{9)}$ Lymphocytes that bind in vitro to sheep erythrocytes in a rosette formation are thymus-derived. In the present communication, the synthesis of two fragment peptides of the thymopoietin II fragment ${ }^{4)}$ was achieved and the in vitro response to uremic serum $^{9)}$ of E-rosette forming cells in the presence of the synthetic peptides was investigated. The solution method for peptide synthesis is used in this investigation. The synthetic routes to the decapeptide (H-Arg-Lys-Asp-Val-Tyr-Val-Gln-Leu-Tyr-Leu-OH) and the nonapeptide (H-Lys-Asp-Val-Tyr-Val-Gln-Leu-Tyr-Leu-OH) are illustrated in Fig. 1.

1) Symbols for amino acid derivatives and peptides are those recommended by the IUPAC-IUB Commission on Biochemical Nomenclature: Biochem. J., 126, 773 (1972). Other abbreviations: WSCI, watersoluble carbodiimide; DMF, dimethylformamide; TFA, trifluoroacetic acid; GVB $^{2+}$, gelatin veronal buffer; FCS, fetal calf serum; Tos, $p$-toluenesulfonic acid; E, sheep erythrocytes; HONB, N-hydroxy5-norbornene-2,3-dicarboximide; PBS, phosphate-buffered saline; $\mathrm{Et}_{3} \mathrm{~N}$, triethylamine.

2) Location: Tsutsumimachi 3-16-1, Sendai, 980, Japan.

3) D.H. Schlesinger and G. Goldstein, Cell, 5, 361 (1975).

4) D.H. Schlesinger, G. Goldstein, P.S. Margrit, and A.B. Edward, Cell, 5, 367 (1975).

5) L. Bernardi, G. Bosisio, F. Chillemi, G. de Caro, R. Castiglione, V. Erspamer, A. Glaesser, and O. Goffredo, Exp., 20, 306 (1964).

6) G.J. Dammin, N.P. Couch, and J.E. Murray, Ann. N.Y. Acad. Sci., 64, 967 (1957).

7) W.E.C. Wilson, C.H. Krkpatrick, and D.W. Talmage. Ann. Intern. Med., 62, 1 (1965).

8) S. Kasakura and L. Lowenstein, Transplantation, 5, 283 (1967).

9) W. Rowiński, H. Lukaswicz, T. Ortowski, and W. Sluzewska, Proc. Eur. Dialysis and Tramsplant Assoc., 9, 507 (1972). 


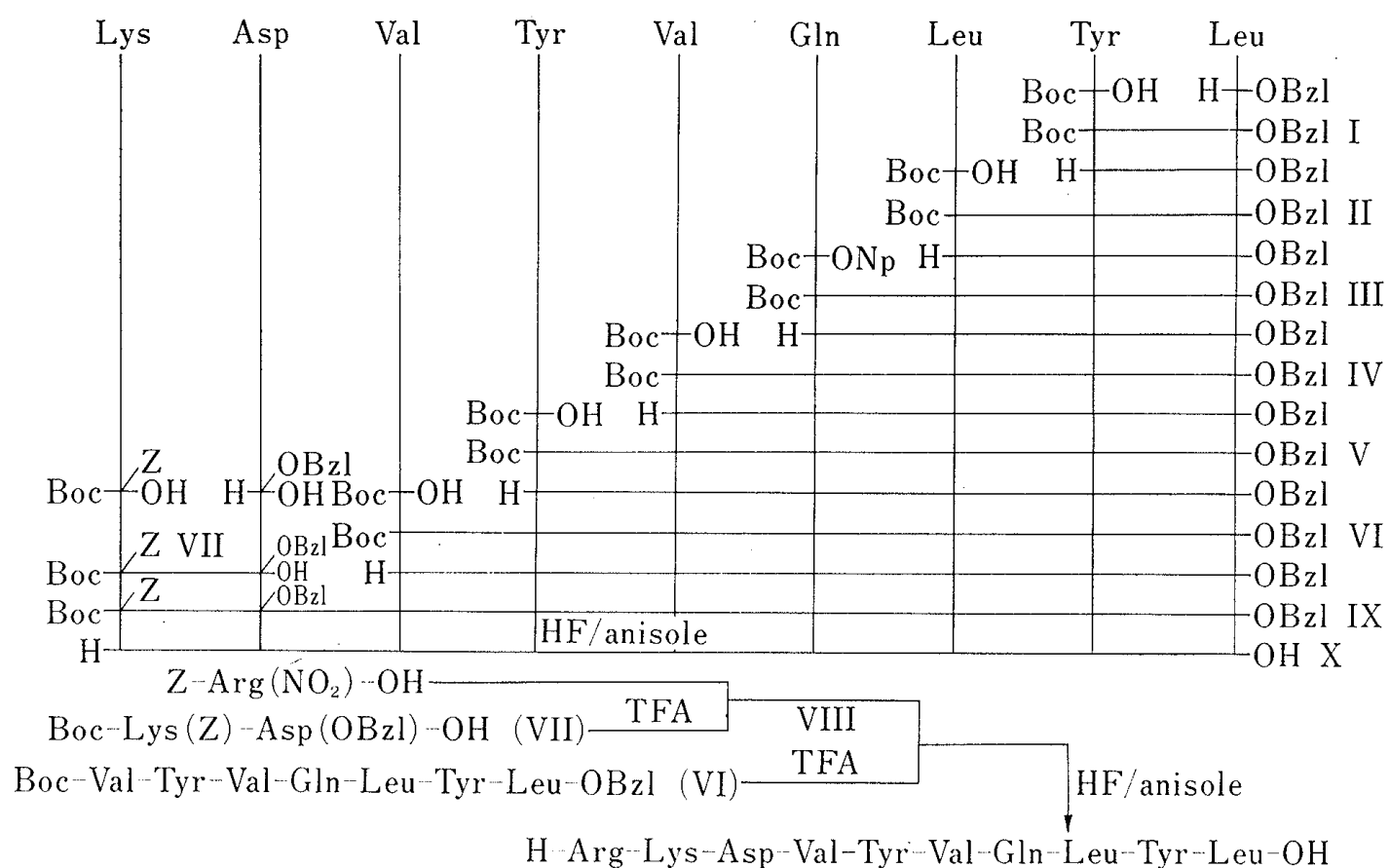

Fig. 1. Synthetic Scheme for the Thymopoietin II Nona- and Decapeptides

H-Leu-OBzl Tos was condensed with Boc-Tyr-OH by the HONB-DCC method ${ }^{10}$ giving Boc-Tyr-Leu-OBzl (I). The protected dipeptide I was treated with TFA to remove the Boc group and the product was coupled with Boc-Leu-OH by the HONB-DCC method to give Boc-Leu-Tyr-Leu-OBzl (II). The Boc group of the tripeptide II was similarly removed and the free base was condensed with Boc-Gln-ONp to afford Boc-Gln-Leu-Tyr-Leu-OBzl (III). The Boc group of the tetrapeptide III was similarly removed and the free base was condensed with Boc-Val-OH by the HONB-DCC method to afford Boc-Val-Gln-Leu-TyrLeu-OBzl (IV). The Boc group of IV was again similarly removed and the free base was condensed with Boc-Tyr-OH by the HONB-DCC method to afford Boc-Tyr-Val-Gln-LeuTyr-Leu-OBzl (V). As before, the Boc group of $\mathrm{V}$ was removed and the free base was condensed with Boc-Val-OH by the HONB-DCC method to afford Boc-Val-Tyr-Val-GinLeu-Tyr-Leu-OBzl (VI). Boc-Lys(Z)-OH was condensed with $\mathrm{H}-\mathrm{Asp}(\mathrm{OBzl})-\mathrm{OH}$ by the mixed anhydride procedure ${ }^{11)}$ to give Boc-Lys $(Z)-A s p(O B z l)-O H$ (VII), which after conversion to the de-Boc peptide, was further condensed with $Z-\operatorname{Arg}\left(\mathrm{NO}_{2}\right)-\mathrm{OH}$ by the mixed anhydride procedure to give $\mathrm{Z}-\operatorname{Arg}\left(\mathrm{NO}_{2}\right)-\mathrm{Lys}(\mathrm{Z})-\mathrm{Asp}(\mathrm{OBzl})-\mathrm{OH}$ (VIII). The heptapeptide VI was treated with TFA and the product was condensed with VII by the HONB-DCC method to give Boc-Lys(Z)-Asp(OBzl)-Val-Tyr-Val-Gln-Leu-Tyr-Leu-OBzl (IX). The protected nonapeptide IX was then treated with anhydrous hydrogen fluoride ${ }^{12)}$ in the presence of anisole at $0^{\circ}$ for 30 min to remove all protecting groups and the deblocked peptide was converted into the corresponding acetate with Amberlite CG- $4 \mathrm{~B}$ (acetate form). The product was purified by column chromatography on Sephadex G-15. The nonapeptide (X) thus obtained was found to be homogeneous on paper chromatography using two different solvent systems. The Boc group of the heptapeptide VI was removed as described above and the free base was condensed with VIII by the HONB-DCC method to give $Z-A r g\left(\mathrm{NO}_{2}\right)-$ Lys(Z)-Asp(OBzl)-Val-Tyr-Val-Gln-Leu-Tyr-Leu-OBzl (XI). Deblockings of XI as describ-

10) M. Fujino, S. Kobayashi, M. Obayashi, T. Fuluda, S. Shinagawa, and O. Nishimura, Chem. Pharm. Bull. (Tokyo), 22, 1857 (1974); C. Kitada and M. Fujino, Chem. Pharn. Bull. (Tokyo), 26, 585 (1978).

11) G.W. Anderson, F.M. Callahan, and J.E. Zimmerman, J. Am. Chem. Soc., 89, 178 (1967).

12) S. Sakakibara and Y. Shimonishi, Bull. Chen. Soc. Jpn, 38, 1412 (1965). 
TABLE I. Effects of Thymopoietin II Fragments on the Inhibition of E-Rosette Formation by Uremic Serum

\begin{tabular}{ccc}
\hline Material & $\begin{array}{c}\text { Dose } \\
(\mu \mathrm{g} / \mathrm{ml})\end{array}$ & $\begin{array}{c}\text { E-Rosettes } \\
(\%)\end{array}$ \\
\hline$-a)$ & & 77 \\
& & 42 \\
H-Lys-Asp-Val-Tyr-Val-Gln-Leu-Tyr-Leu-OH $c)$ & 10 & 44 \\
& 50 & 45 \\
H-Arg-Lys-Asp-Val-Tyr-Val-Gln-Leu-Tyr-Leu-OH $c)$ & 100 & 42 \\
& 10 & 53 \\
& 50 & 59 \\
& 100 & 66
\end{tabular}

a) Normal lymphocytes.

b) Lymphocytes were incubated for 30 min at $37^{\circ}$ with uremic serum.

c) Lymphocytes were incubated for $30 \mathrm{~min}$ at $37^{\circ}$ with uremic serum and thymopoietin II fragments.

ed for the preparation of the nonapeptide $\mathrm{X}$ yielded the desired H-Arg-Lys-Asp-Val-TyrVal-Gln-Leu-Tyr-Leu-OH (XII).

Serum from an uremic patient with chronic renal failure had low proportions of T-cell rosettes, ranging from 39 to $42 \%$. After incubation with amounts of the decapeptide varying from 10 to $100 \mu \mathrm{g} / \mathrm{ml}$ of cell suspension, maximum T-cell rosette formation ranged from 53 to $66 \%$ (Table I). The nonapeptide has no effect on the E-rosette formation inhibiting activity of uremic serum at a dose of $100 \mu \mathrm{g} / \mathrm{ml}$. These results strongly suggest that the lower limit of peptide chain length for agonistic activity towards E-rosette formation inhibition by uremic serum is the decapeptide (XII). The results also suggest strongly that the N-terminal arginine residue of the decapeptide plays an important role in eliciting full agonistic activity towards E-rosette inhibition by uremic serum.

\section{Experimental}

All melting points are uncorrected. Rotations were determined with an Atago Polax machine. The amino acid hydrolysates and aminopeptidase M (AP-M) digests ${ }^{13}$ ) were analyzed with a JEOL J,LC-8AH amino acid analyzer according to the directions given by Moore et al. ${ }^{14}$ ) The $Z$-group of the protected peptide was deblocked by catalytic hydrogenation in the presence of $10 \% \mathrm{Pd}-\mathrm{C}$, and the Boc group with TFA. The deblocked peptides were chromatographed on filter paper, Toyo Roshi No. 51, at room temperature. Rf ${ }^{1}$ values refer to the Partridge system $\left.{ }^{15}\right)$ and $R f^{2}$ values refer to a system of $\mathrm{BuOH}-$-pyridine-AcOH$-\mathrm{H}_{2} \mathrm{O}(30: 20$ : $6: 24){ }^{16)}$ Evaporations were carried out in a rotary evaporator under reduced pressure at a temperature of $30-35^{\circ}$. Uremic blood was obtained from an uremic patient suffering from terminal chronic renal failure. The blood was centrifuged and the separated serum was stored at $-20^{\circ}$ until use.

Boc-Tyr-Leu-OBzl (I) - H-Leu-OBzl Tos (3.9 g) was condensed with Boc-Tyr-OH (3.1 g) in DMF $(30.0 \mathrm{ml})$ in the presence of $\mathrm{Et}_{3} \mathrm{~N}(1.5 \mathrm{ml})$, HONB $(1.8 \mathrm{~g})$ and WSCI $(2.0 \mathrm{~g})$ at $0^{\circ}$ for $18 \mathrm{hr}$. The mixture was diluted with EtOAc and the solution was washed with $1 \mathrm{~N} \mathrm{NaHCO}_{3}, \mathrm{H}_{2} \mathrm{O}, 1 \mathrm{~N}$ citric acid and $\mathrm{H}_{2} \mathrm{O}$, then dried over anhydr. $\mathrm{MgSO}_{4}$, and the solvent was evaporated off. The residue was precipitated from EtOAc and petroleum ether: $4.5 \mathrm{~g}(94 \%), \operatorname{mp} 52-53^{\circ},[\alpha]_{\mathrm{D}}^{24}-16.0^{\circ}(c=1.0, \mathrm{DMF}), R f^{1} 0.68, R f^{2} 0.76$, single ninhydrinpositive spot. Anal. Calcd. for $\mathrm{C}_{27} \mathrm{H}_{36} \mathrm{~N}_{2} \mathrm{O}_{6}: \mathrm{C}, 66.92 ; \mathrm{H}, 7.49 ; \mathrm{N}, 5.78$. Found: $\mathrm{C}, 66.51 ; \mathrm{H}, 7.87 ; \mathrm{N}, 5.66$.

Boc-Leu-Tyr-Leu-OBzl (II) _ - I (4.9 g) was dissolved in TFA $(5.0 \mathrm{ml})$ and the solution was allowed to stand at room temperature for $15 \mathrm{~min}$, then evaporated down. The residue was dried over KOH pellets in a vacuum and then dissolved in DMF $(30.0 \mathrm{ml})$ together with $\mathrm{Et} \mathrm{H}_{3} \mathrm{~N}(1.6 \mathrm{ml})$. HONB $(2.0 \mathrm{~g})$, Boc-Leu-OH $(2.6 \mathrm{~g})$ and WSCI $(1.7 \mathrm{~g})$ were added to the above solution at $-10^{\circ}$. The mixture was stirred at $0^{\circ}$ for $18 \mathrm{hr}$ then extracted with EtOAc, and the solution was washed successively with $1 \mathrm{~N} \mathrm{NaHCO}_{3}, \mathrm{H}_{2} \mathrm{O}, 1 \mathrm{~N}$ citric acid and $\mathrm{H}_{2} \mathrm{O}$. The solution was dried over anhydr. $\mathrm{MgSO}_{4}$ and concentrated to a small volume, then petro-

13) K. Hofman, F.M. Fin, J. Montibeller, and G. Zanetti, J. Am. Chem. Soc., 88, 3633 (1966).

14) S. Moore, D.H. Spackman, and W.H. Stein, Anal. Chem., 30, 1185 (1958).

15) S.M. Partridge, Biochem. J., 42, 238 (1948).

16) S.G. Waley and G. Watson, Biochem. J., 55, 328 (1953). 
leum ether was added to the residue. The precipitate thereby formed was reprecipitated from EtOAc and hexane: $4.3 \mathrm{~g}(69 \%), \operatorname{mp} 62-68^{\circ},[\alpha]_{\mathrm{D}}^{24}-39.4^{\circ}(c=1.0, \mathrm{DMF}), R f^{1} 0.78, R f^{2} 0.88$, single ninhydrin-positive spot. Anal. Calcd. for $\mathrm{C}_{23} \mathrm{H}_{47} \mathrm{~N}_{3} \mathrm{O}_{7} \mathrm{H}_{2} \mathrm{O}: \mathrm{C}, 64.37 ; \mathrm{H}, 8.02 ; \mathrm{N}, 6.83$. Found: $\mathrm{C}, 64.83 ; \mathrm{H}, 8.41 ; \mathrm{N}, 7.21$.

Boc-GIn-Leu-Tyr-Leu-OBzl (III)__ II $(1.5 \mathrm{~g})$ was treated with TFA $(2.0 \mathrm{ml})$ and the resuiting residue was dissolved in DMF $(15.0 \mathrm{ml})$ together with $\mathrm{Et}_{3} \mathrm{~N}(0.4 \mathrm{ml})$. Boc-Gln-ONp $(1.2 \mathrm{~g})$ was added and the solution was stirred at room temperature for $18 \mathrm{hr}$. The reaction mixture was poured into cold $1 \mathrm{~N} \mathrm{NH}$ with stirring. Next, $50 \% \mathrm{NH}_{4} \mathrm{OAc}$ was added dropwise with stirring to form a precipitate. The precipitate was collected and washed successively with $1 \mathrm{~N} \mathrm{NH}_{4} \mathrm{OH}, \mathrm{H}_{2} \mathrm{O}, 1 \mathrm{~N}$ citric acid and $\mathrm{H}_{2} \mathrm{O}$. The product was reprecipitated from DMF and $1 \mathrm{~N}$ citric acid: $1.7 \mathrm{~g}(94 \%), \operatorname{mp} 164-168^{\circ},[\alpha]_{\mathrm{D}}^{24}-33.2^{\circ}(c=1.0, \mathrm{DMF}), R f^{1}$ $0.71, R f^{2}$ 0.78, single ninhydrin-positive spot. Anal. Calcd. for $\mathrm{C}_{38} \mathrm{H}_{55} \mathrm{~N}_{5} \mathrm{O}_{9}: \mathrm{C}, 62.87 ; \mathrm{H}, 7.64 ; \mathrm{N}, 9.65$. Found: C, 63.15; H, 7.49; N, 10.09 .

Boc-Val-Gln-Leu-Tyr-Leu-OBzl (IV)___ III (1.500 g) was treated with TFA $(2.0 \mathrm{ml})$ as described above and the resulting residue was dissolved in DMF $(15.0 \mathrm{ml})$ with $\mathrm{Et}_{3} \mathrm{~N}(0.3 \mathrm{ml})$. HONB $(394 \mathrm{mg})$, Boc-Val$\mathrm{OH}(479 \mathrm{mg})$ and WSCI $(341 \mathrm{mg})$ were added to this solution at $-10^{\circ}$. The mixture was stirred at $0^{\circ}$ for $18 \mathrm{hr}$, then poured into cold $1 \mathrm{~N} \mathrm{NaHCO}_{3}$ with stirring. Next, $50 \% \mathrm{NH}_{4} \mathrm{OAc}$ was added dropwise with stirring to form a precipitate. The precipitate was collected and washed successively with $1 \mathrm{~N} \mathrm{NH} \mathrm{OH}_{4}$, $\mathrm{H}_{2} \mathrm{O}, 1 \mathrm{~N}$ citric acid and $\mathrm{H}_{2} \mathrm{O}$. The product was reprecipitated from DMF and $1 \mathrm{~N}$ citric acid: $1.2 \mathrm{~g}(71 \%)$, $\operatorname{mp} 207-212^{\circ},[\alpha]_{\mathrm{D}}^{25}-45.8^{\circ}(c=1.0, \mathrm{DMF}), R f^{1} 0.87, R f^{2} 0.91$, single ninhydrin-positive spot. Anal. Calcd. for $\mathrm{C}_{43} \mathrm{H}_{64} \mathrm{~N}_{6} \mathrm{O}_{10}: \mathrm{C}, 62.60 ; \mathrm{H}, 7.82 ; \mathrm{N}, 10.19$. Found: C, 62.19; H, 7.88; $\mathrm{N}, 9.91$.

Boc-Tyr-Val-GIn-Leu-Tyr-Leu-OBzl (V)_-This compound was prepared from IV (825 mg), HONB $(198 \mathrm{mg})$, Boc-Tyr-OH $(309 \mathrm{mg})$ and WSCI $(171 \mathrm{mg})$ essentially as described for the preparation of IV: $800 \mathrm{mg}(81 \%), \operatorname{mp} 170-190^{\circ},[\alpha]_{\mathrm{D}}^{25}-46.3^{\circ}(c=1.0, \mathrm{DMF}), R f^{1} 0.88, R f^{2} 0.91$, single ninhydrin-positive spot. Anal. Calcd. for $\mathrm{C}_{52} \mathrm{H}_{73} \mathrm{~N}_{7} \mathrm{O}_{12}: \mathrm{C}, 63.20 ; \mathrm{H}, 7.45 ; \mathrm{N}, 9.92$. Found: C, 62.86; H, 7.68; N, 9.45.

Boc-Val-Tyr-Val-Gln-Leu-Tyr-Leu-OBzl (VI)__This compound was prepared from V (494 mg), HONB $(99 \mathrm{mg})$, Boc-Val-OH $(155 \mathrm{mg})$ and WSCT $(86 \mathrm{mg})$ essentially as described for the preparation of IV: $430 \mathrm{mg}$ $(79 \%), \mathrm{mp} 189-199^{\circ},[\alpha]_{\mathrm{D}}^{25}-45.8^{\circ}(c=1.0, \mathrm{DMF}), R f^{1} 0.91, R f^{2} 0.94$, single ninhydrin-positive spot. Anal. Calcd. for $\mathrm{C}_{57} \mathrm{H}_{82} \mathrm{~N}_{8} \mathrm{O}_{13}: \mathrm{C}, 62.96 ; \mathrm{H}, 7.60 ; \mathrm{N}, 10.13$. Found: C, 63.01; H, 7.66; N, 9.98 .

Boc-Lys $(\mathbf{Z})-\mathbf{A s p}(\mathbf{O B z l})-\mathbf{O H}$ (VII)_-A solution of Boc-Lys $(Z)-\mathrm{OH}$ (3.8 g) and N-methylmorpholine $(1.1 \mathrm{ml})$ in a mixture of tetrahydrofuran $(5.0 \mathrm{ml})$ and acetonitrile $(5.0 \mathrm{ml})$ was cooled to $-10^{\circ}$ and ethylchlorocarbonate $(1.0 \mathrm{ml})$ added thereto. After $15 \mathrm{~min}$, a precooled solution of $\mathrm{H}-\mathrm{Asp}(\mathrm{OBzl})-\mathrm{OH}(2.3 \mathrm{~g})$ and $\mathrm{N}$-methylmorpholine $(1.0 \mathrm{ml})$ in DMF $(5.0 \mathrm{ml})$ was added and the reaction mixture was left overnight at $4^{\circ}$. The mixture was extracted with EtOAc and washed successively with $1 \mathrm{~N}$ citric acid and $\mathrm{H}_{2} \mathrm{O}$. The solvent was dried over anhydr. $\mathrm{MgSO}_{4}$ and evaporated off in a vacuum. The residue was precipitated from EtOAc and petroleum ether: $3.6 \mathrm{~g}(62 \%), \operatorname{mp} 50-51^{\circ},[\alpha]_{\mathrm{D}}^{24}-17.0^{\circ}(c=1.0, \mathrm{DMF}), R f^{1} 0.42, R f^{2} 0.52$, single ninhydrinpositive spot. Anal. Calcd. for $\mathrm{C}_{30} \mathrm{H}_{39} \mathrm{~N}_{3} \mathrm{O}_{9}: \mathrm{C}, 61.52 ; \mathrm{H}, 6.71 ; \mathrm{N}, 7.18$. Found: $\mathrm{C}, 61.16 ; \mathrm{H}, 7.02 ; \mathrm{N}, 6.91$.

Z-Arg $\left(\mathbf{N O}_{2}\right)-\mathbf{L y s}(\mathbf{Z})-\mathbf{A s p}(\mathbf{O B z l})-\mathbf{O H}$ (VIII)__VII (1.200 g) was treated with TFA (2.0 ml) as described above and the resulting residue was dissolved in DMF $(5.0 \mathrm{ml})$. A solution of $Z-A \operatorname{rg}\left(\mathrm{NO}_{2}\right)-\mathrm{OH}(0.780 \mathrm{~g})$ and $\mathrm{N}$-methylmorpholine $(0.2 \mathrm{ml})$ in a mixture of tetrahydrofuran $(5.0 \mathrm{ml})$ and acetonitrile $(5.0 \mathrm{ml})$ was cooled to $-10^{\circ}$ and treated with ethylchlorocarbonate $(0.3 \mathrm{ml})$. After standing for some $25 \mathrm{~min}$, a cold DMF solution of $\mathrm{H}-\mathrm{Lys}(\mathrm{Z})-\mathrm{Asp}(\mathrm{OBzl})-\mathrm{OH}$ trifluoroacetate and $\mathrm{N}$-methylmorpholine $(0.22 \mathrm{ml})$ was added, and the mixture was allowed to stand overnight at $4^{\circ}$. The mixture was evaporated down in a vacuum, extracted with EtOAc, and washed with $1 \mathrm{~N} \mathrm{HCl}$ and $\mathrm{H}_{2} \mathrm{O}$. The solvent was dried over anhydr. $\mathrm{MgSO}_{4}$ and evaporated down in a vacuum. The residue was precipitated from EtOAc and ether: $1.2 \mathrm{~g}(71 \%), \mathrm{mp} 58-59^{\circ}$, $[\alpha]_{\mathrm{D}}^{24}$ $-42.0^{\circ}(c=1.0, \mathrm{DMF})$. Anal. Calcd. for $\mathrm{C}_{39} \mathrm{H}_{49} \mathrm{~N}_{8} \mathrm{O}_{12}: \mathrm{C}, 57.09 ; \mathrm{H}, 6.01 ; \mathrm{N}, 13.64$. Found: C, 56.80; $\mathrm{H}$, $5.88 ; \mathrm{N}, 13.65$.

Boc-Lys $(Z)$-Asp (OBzl)-Val-Tyr-Val-Gln-Leu-Tyr-Leu-OBzl (IX)- - This compound was prepared from VI (155 mg), HONB (29 mg), VII (95 mg) and WSCI (25 mg) essentially as described for the preparation of IV. The dried product was reprecipitated from EtOH and $\mathrm{H}_{2} \mathrm{O}: 203 \mathrm{mg}(91 \%), \mathrm{mp} 166-174^{\circ},[\alpha]_{\mathrm{D}}^{25}-35.5^{\circ}$ $(c=1.0, \mathrm{DMF}), R f^{1} 0.88, R f^{2} 0.93$, single ninhydrin-positive spot. Anal. Calcd. for $\mathrm{C}_{82} \mathrm{H}_{111} \mathrm{~N}_{11} \mathrm{O}_{19}: \mathrm{C}, 63.34 ; \mathrm{H}$, $7.20 ; \mathrm{N}, 9.90$. Found: C, $62.91 ; \mathrm{H}, 7.45 ; \mathrm{N}, 10.11$.

H-Lys-Asp-Val-Tyr-Val-GIn-Leu-Tyr-Leu-OH (X)__The above protected nonapeptide (180 mg) was treated with HF (approximately $10.0 \mathrm{ml}$ ) in the presence of anisole $(0.2 \mathrm{ml}$ ) in an ice bath for $30 \mathrm{~min}$. After removal of $\mathrm{HF}$ by evaporation, was stored over $\mathrm{KOH}$ pellets in a vacuum and the residue was dissolved in a small amount of $\mathrm{H}_{2} \mathrm{O}$, which was washed with EtOAc then treated with Amberlite CG-4B (type 1, acetate form, $5 \mathrm{~g}$ ) for $30 \mathrm{~min}$. The resin was removed by filtration, the filtrate was lyophilized and the residue was dissolved in a small amount of $1 \% \mathrm{AcOH}$. The solution was applied to a column of Sephadex G-15 (2.8 $\times 60.0$ $\mathrm{cm}$ ), and eluted with the same solvent. Individual fractions (4 $\mathrm{ml}$ each) were collected and the absorbancy at $260 \mathrm{~nm}$ was determined. Fractions corresponding to the main peak (tube Nos. 38-52) were combined. The solution was concentrated in vacuo and the product lyophilized: $60 \mathrm{mg}(46 \%), \mathrm{mp} 140-150^{\circ},[\alpha]_{\mathrm{D}}^{25}-55.0^{\circ}$ $\left(c=1.0, \mathrm{H}_{2} \mathrm{O}\right), R f^{1} 0.03, R f^{2} 0.11$, single ninhydrin-positive spot. Amino acid ratios in the acid hydrolysate: Leu 1.90, Tyr 1.81, Val 1.89, Glu 0.91, Asp 1.00, Lys 0.98 (average recovery $84 \%$ ). Amino acid ratios in the AP-M digest: Leu 1.94, Tyr 1.90, Val 2.00, Gln 0.90, Asp 0.91, Lys 0.94 (average recovery $81 \%$ ). 
Z-Arg $\left(\mathbf{N O}_{2}\right)$-Lys $(\mathbf{Z})$-Asp(OBzl)-Val-Tyr-Val-GIn-Leu-Tyr-Leu-OBzl (XI) _- This compound was prepared from VI $(218 \mathrm{mg})$, HONB $(39 \mathrm{mg})$, VIII $(180 \mathrm{mg})$ and WSCI (34 mg) essentially as described for the preparation of IV. The product was recrystallized from EtOH and $\mathrm{H}_{2} \mathrm{O}: 310 \mathrm{mg}(85 \%), \mathrm{mp} 141-150^{\circ},[\alpha]_{\mathrm{D}}^{25}-39.5^{\circ}$ $(c=1.0, \mathrm{DMF})$. Anal. Calcd. for $\mathrm{C}_{91} \mathrm{H}_{122} \mathrm{~N}_{16} \mathrm{O}_{23} \mathrm{H}_{2} \mathrm{O}: \mathrm{C}, 60.45 ; \mathrm{H}, 6.80 ; \mathrm{N}, 12.40$. Found: $\mathrm{C}, 59.51 ; \mathrm{H}$, $7.31 ; \mathrm{N}, 11.80$.

H-Arg-Lys-Asp-Val-Tyr-Val-Gln-Leu-Tyr-Leu-OH (XII)__The decapeptide was prepared from XI $(200 \mathrm{mg})$ essentially as described for the preparation of X. XI was treated with $\mathrm{HF}$ at $0^{\circ}$ for $30 \mathrm{~min}$. The deblocked peptide was applied to a column $(2.0 \times 60.0 \mathrm{~cm})$ of Sephadex G-15 and eluted with $10 \% \mathrm{AcOH}$. The eluates in the Nos. 31 to 50 containing the decapeptide were pooled and treated in the usual way: $68 \mathrm{mg}$ $(48 \%), \operatorname{mp} 184-198^{\circ},[\alpha]_{\mathrm{D}}^{25}-64.5^{\circ}\left(c=1.0, \mathrm{H}_{2} \mathrm{O}\right), R f^{1} 0.03, R f^{2} 0.10$, single ninhydrin- and Sakaguchi-positive spot. Amino acid ratios in the acid hydrolysate: Leu 1.82, Tyr 1.78, Val 1.91, Glu 0.89, Asp 0.91, Arg 0.98, Lys 1.00 (average recovery $81 \%$ ). Amino acid ratios in the AP-M digest: Leu 1.91, Tyr 1.88, Val 1.99, Gln 0.91, Asp 0.98, Arg 0.99, Lys 0.91 (average recovery $81 \%$ ).

E-Rosette Formation Procedure ${ }^{17}$ ) _ Peripheral lymphocytes were isolated by Hypaque-Ficoll gradient centrifugation. For $T$ cell rosette formation, isolated lymphocytes were adjusted to a concentration of $5 \times 10^{5} \mathrm{ml}$ with PBS. Contamination with monocytes and polymorphonuclear cells was less than $5 \%$. Sheep erythrocytes were washed with PBS and a suspension $\left(1 \times 10^{6} / \mathrm{ml}\right)$ was prepared. Lymphocytes were suspended in $\mathrm{GVB}^{2+}$ or FCS $(0.7 \mathrm{ml})$ and incubated for 30 min at $37^{\circ}$ with uremic serum $(0.3 \mathrm{ml})$ and the synthetic peptides. Lymphocytes were washed with $\mathrm{GVB}^{2+}$ and centrifuged for $10 \mathrm{~min}$ at $1500 \mathrm{rpm}$, then suspended in $\mathrm{GVB}^{2+}$ or FCS $(1.0 \mathrm{ml})$. The suspension was mixed with sheep erythrocytes $(0.5 \mathrm{ml})$ and then incubated for $18 \mathrm{hr}$ at $4^{\circ}$. The mixture was centrifuged for $5 \mathrm{~min}$ at $900 \mathrm{rpm}$. Triplicate wet-cell preparations were studied by phase microscopy. In each preparation, 200 lymphocytes were counted, and the proportion binding three or more sheep erythrocytes (rosettes) was determined (normal, $77 \%$ ). Monocytes or polymorphonuclear cells forming rosettes were excluded (Table I).

Acknowledgement The authors thank the Central Analysis Laboratory, Pharmaceutical Institute, Tohoku University, for elemental analysis.

17) J. Wybran, H.H. Fudenberg, and M.H. Sleisenger, Clin. Res., 19, 568 (1971). 